\title{
Breaking the mainstream mold: The birth of a local political cartoonist in post-3.11 Japan
}

\author{
Ronald Stewart \\ Prefectural University of Hiroshima, Japan \\ ronstewart@pu-hiroshima.ac.jp
}

\begin{abstract}
This paper introduces the Disaster Picture-Diary political cartoons of Asakura Yūzō which appear in the Japanese regional newspaper Fukushima Minpō. After the socalled 3.11 disaster's triple blow of earthquake, tsunami, and multiple nuclear reactor meltdowns in 2011, intense public and media interest and debates erupted over: how to help the victims; how to rebuild; what to do about the ongoing nuclear problem; and what should be the future of direction the nation. Yet, cartoonists in national daily newspapers failed to get involved in much of this debate. They basically continued on as they had done before the disaster merely lightly mocking politicians, their eyes closed to wider problems. In contrast, Asakura's cartoons which began in the wake of 3.11 in the disaster affected region, broke away from this mainstream form of cartoon discourse to comment on a much greater variety of post-3.11 issues using a much more diverse range of drawing styles. In this sense, though still seemingly restrained to an outside observer from a country with a more aggressive satirical cartooning, for Asakura it is definitely a case of "anything goes". This paper gives an overview of the disaster, and mainstream political cartooning before and after 3.11. It then introduces examples of Asakura's Disaster Picture-Diary political cartoons, contrasting them with mainstream national cartoons to underscore how his work differs. In concluding, a number of reasons for these differences are provisionally forwarded.
\end{abstract}

Keywords: political cartoons, newspaper cartoons, satire, Japan, Fukushima, disaster, earthquake, tsunami, nuclear accident, 3.11. 


\section{Introduction}

Political cartoonists for Japan's major daily newspapers with their huge circulations enjoy an audience reach that cartoonists in other countries would envy. Yet, despite this wide exposure their cartoons seem to draw scant attention. For decades Japanese newspaper political cartoons, many drawn in similar styles, have tended to provide rather bland explanations or commentary narrowly focused on the world of politics, rarely provoking controversy or packing satirical punch. This state has drawn criticism from academics as well as practitioners. Political scientist Sodei Rinjirō feels Japanese political cartoons lack a sense of attack (McNicol 2005), and veteran political cartoonist Yamanoi No-rio (2007) laments Japanese newspaper cartoons' lack of quality and popularity. Consequently, the cartoons are easily overlooked, failing to draw attention to issues or provoke thought. That is, not only have they been failing in their role as entertainment, but for decades political cartoons in Japan have also generally fallen short in fulfilling another of their primary functions, that of agenda-setting, or framing of issues. This function of identifying issues and values and giving them salience, and offering readers models of understanding, is possibly the most significant role cartoons play in societies (DeSousa \& Medhurst 1982; Edwards 1997: 7-8).

Perhaps the only way to shake Japanese newspaper political cartooning from its lethargy would be a national crisis large enough to infuse it with a sense of urgency. On 11 March 2011 such a crisis came: The Great East Japan Earthquake. This was a triple disaster - earthquake, tsunami and nuclear accident - that brought immense damage on a scale that will take decades to fully recover from. It led to intense political and public debate throughout the nation not only about how to best help victims and reconstruct the region, but also on the future of energy use and the future of the country itself. Some saw it as a deathblow for a nation that was already stagnating, some made use of the disaster to forcefully reassert their previous positions (stay the course), and others saw it as a chance for renewal and rejuvenation of the nation (Samuels 2013). Unfortunately, not much of the urgency of these debates rubbed off on the cartoonists at the major dailies, who continued in their limited, relatively uncritical way. The one exception in Japanese newspaper cartooning was in a regional newspaper which began a serialised weekly political cartoon by Asakura Yūzō called Disaster Picture-Diary (Shinsai no enikki). Unlike those in the national papers, Asakura's cartoons actively engage in post3.11 political and social problems. This paper will introduce and contrast examples of his work with cartoons of the major national dailies. After which some provisional conclusions will be presented about why this cartoonist has been able to break the Japanese mainstream cartooning mold. Before doing this however, a sense of the enormity of the disaster and some more background on Japanese newspaper cartooning is necessary.

\section{Scale of disaster and public response}

On 11th of March 2011, the northeastern coast of Japan's main island Honshū was hit by a triple disaster, earthquake, tsunami and nuclear accident leading to multiple reactor meltdowns at Tokyo Electric Power Company's (TEPCO) Fukushima Daiichi Power 
Plant. The disaster is officially known as the Great East Japan Earthquake, but is more commonly referred to as simply 3.11. The country was left reeling from the human and material cost of the disaster. According to official statistics, confirmed deaths number 15,884 people, with an additional 2,636 people unaccounted for (Kyodo 2014). The quake and tsunami collapsed or half collapsed 368,862 buildings and homes and damaged countless others (Kazama \& Noda 2012: 789). Infrastructure was also badly hit. The tsunami inundated three airports, fourteen international ports, and 260 fishing harbours leaving them badly damaged or destroyed (Samuels 2013: 7). Approximately 4,000 sections of road, 78 bridges and 29 sections of railroad were damaged (BBC News 2012). Moreover, those who survived the disaster continue to live in difficult situations as the slow reconstruction takes place. A peak of 470,000 people were displaced by the disasters, and three years later approximately 267,000 still lived in some form of temporary accommodation (Kyodo 2014). As many as 54,000 evacuees forced from their homes due to radiation levels will not be able to return until after 2017, but many, 30 to $50 \%$ of evacuees surveyed do not intend to return (Kasai 2013). By early 2014, an estimated 3,048 evacuees living in shelters had died due to suicide or stress (Kyodo 2014). While progress in rebuilding and resettling has been made, many remaining and returning communities have also been badly fractured, with deep divisions over the future direction of their hometowns (where and how to rebuild), and tensions, bitterness and feelings of guilt caused by differing levels of damage, and the receipt of differing compensation payment amounts.

Beyond the directly affected region, 3.11 also shook the whole country not only in terms of the shocking damage and loss of human life, but also politically and socially. People throughout the country were spurred into action, donating food, money, time and labour. About 935,000 volunteers headed for Fukushima to help out just in the first year after the disaster, and numerous NGOs sprung up from nowhere specifically to help (Samuel 2013:18). Initial expectations over the central government's and TEPCO's response to the disaster turned to disappointment with public support plummeting for both over the months following 3.11. There was anger over their slow, ineffective and bungling responses. There was also suspicion that the government and TEPCO were playing down the dangers of radioactive fallout, and trying to avoid responsibility for a lack of adequate disaster planning by claiming the scale of the disaster was "unimaginable" (sōteigai). The disaster brought to the fore issues of leadership, responsibility, information access, excessively close relationships between industry and government, the use and misuse of public money, health concerns, the future of the nuclear industry and alternative energy, and indeed the future of the nation. The nuclear power plant meltdowns strengthened anti-nuclear sentiment in the country, resulting in some of the largest public demonstration rallies seen in Japan in decades, such as the 16 July 2012 anti-nuclear rally of 170,000 people (see Samuels 2013 for a fuller discussion on political and public debate in the wake of 3.11.) Over the three years following the disaster, general public and media interest in the affected areas and the reconstruction process has somewhat waned, but these issues have been and remain important not just for the disaster hit areas but for the whole nation. These pressing issues that stirred such intense public and media debate should have provided much potential fodder for satirical cartoonists. But, how did Japan's political cartoonists react? Let us now look at the situation in mainstream Japanese newspaper cartooning leading up to 3.11, before briefly discussing their reaction to the disaster and ongoing related problems. 


\section{The Sate of Newspaper Political Cartooning and Its Reaction to 3.11}

Japanese newspaper cartooning is dominated by the "big three newspapers" (daisanshi) national dailies-Yomiuri Shinbun, Asahi Shinbun and Mainichi Shinbun-plus one news distribution service-Kyodo News. Political cartooning in Japan's major newspapers enjoyed its heyday in the 1950s, with some cartoonists, such as Yomiuri Shinbun's Kondō Hidezō (1908-1979), becoming household names. In his book on Japanese newspaper cartoons, political scientist Ibaragi Masaharu (2007: 71-93) has charted the postwar rise and, from the late 1960s, the decline in the satire, prominence and frequency of Japanese political cartooning. Between the mid-1950s and 1970 they were a selling point for newspapers: all three of the national newspapers ran political cartoons on their front pages. After this they were moved to interior pages. From the late 1980s newspapers began reducing the number of cartoons they ran. Cartoons had once appeared in both morning and evening editions but by the end of the 1990s they had disappeared from the evening editions, and were no longer daily in the morning editions.

At the time of surveying cartoons for this paper, the right-of-centre newspaper Yomiuri Shinbun which boasts the largest circulation, around 10 million, was running three to four cartoons a week on its political news page. These were drawn in rotation by three cartoonists each allotted a day, or days, of the week. The Asahi Shinbun, a left leaning newspaper with a circulation of around eight million, had five cartoons per week on the opinion page using three cartoonists in a weekly rotation. The most politically neutral of the "big three" Mainichi Shinbun, circulation approximately five and a half million, had four cartoons per week with three cartoonists allotted days and sections - economics news, general news and entertainment news. The news service Kyodo News, which supplies news articles, photos and artwork to over 60 regional newspapers, had about five cartoonists producing a total of five to seven cartoons per week. In general, regional newspapers do not have their own cartoonists, and those that do run political cartoons buy four to five per week from Kyodo News. As can be seen here, the number of cartoon voices offered by newspapers to the public was very limited, four news organisations with about 16 cartoonists accounting for almost all of newspaper cartoon discourse in a country of 130 million people. (Since completing this survey the Yomiuri Shinbun has stopped running political cartoons altogether, beginning May 2013, so the variety in political cartoon commentary has now become even more restricted.)

These Japanese newspaper political cartoons are also limited in other ways. Firstly, they are very narrowly focused on the world of Japanese politicians, only occasionally touching on international politics, and even less frequently engaging in social satire. Moreover, while it has long been the case that politicians are fair game for Japanese cartoonists, other sections of the government, the judiciary, as well as other non-elected officials or bureaucrats of the various government ministries and agencies are not. Although they are occasionally open to criticism in writing in newspapers, they seem to be above, almost a taboo subject for, cartoon criticism. Moreover, cartoons critiquing the business world also are almost nonexistent. The reasons for this blinkered focus on politicians are in part historical. Newspaper cartoons since the 1950s had been mostly split into seiji (political) and sesō (social, or more literally state-of-the-times) 
satirical cartoons. The political cartoons were traditionally placed in the general news, politics or economy pages of morning papers, while social cartoons appeared in the evening and/or weekend editions. This was a division in labour, theme and placement for newspaper cartoons not found in the newspapers such as those in the United States or Australia, where both the political and social would be included within a broader usage of the term "political cartoon" or "editorial cartoon," with most cartoonists comfortable doing either. When Japanese newspapers started reducing their use of cartoons from the late 1980s, it was the social cartoons that lost out the most (Ibaragi 2007: 85-91). Now, even though Japanese political cartoons have supposedly taken over the role of the former social cartoons, and are, in newspapers like Asahi and regional dailies, placed on the op-ed pages where they should have more freedom to comment on a variety of subjects, and even though Kyodo News cartoons are also now labeled "sesō manga" (state-of-the-times cartoons), the critical gaze of Japanese newspaper cartoonists remains firmly fixed on politicians.

Japanese newspaper political cartoons have also long been limited in their satirical bite. To indicate where they lie in the spectrum of cartooning, it may be useful here to draw on the taxonomy (modified from Press 1981) suggested by Manning \& Phiddian (2004b: 27-32) to classify political cartoon types. These types are: a) the descriptive cartoon which just explains the way things are; b) the laughing satirical cartoon which criticises but does not seek to undermine the legitimacy of their target; c) the savagely indignant cartoon which has more of a sense of urgency and questions legitimacy without wanting to completely destroy the system; and d) the destructive satirical cartoon which is revolutionary in nature denying the humanity of the target and rejecting the system. The greater half of newspaper political cartoons drawn over the last two decades in Japan would fall into the descriptive cartoon category. In the case of Yomiuri Shinbun, the vast majority of their cartoons would tend to fall into this category. In Japanese these are called etoki (explanation pictures), and while employing humorous-looking caricatures, gags and puns, they merely seek to sum up situations, offering no critical standpoint or satire. Almost all of the rest of the political cartoons produced in Japan would fall into the laughing satirical category, the most biting of which are produced by Yamada Shin and Yaku Mitsuru of the Asahi Shinbun, and Yokota Shigi of the Mainichi Shinbun. But even so these, in comparison to political cartoons in Anglophone countries or France for example, are quite mild. The targets of their satire also appear to have become more superficial over the decades. Whereas in the 1950s ideologies and deeper political structures where questioned, more recent political cartoons appear more intent on making mild fun of political personalities and their politicking (see Ibaragi 2007). According to Sodei Rinjirō, Japanese political cartoons are "just funny pictures about politicians" (quoted in McNicol 2005).

Cultural preferences and commercial concerns no doubt also play some role in this. Marguerite Wells (2006) has argued that there are cultural reasons for low instance and mildness of satire in Japan: the traditional avoidance of the negative aspects of humour, resulting in discomfort with the attack or aggression of satire; and a traditional preference for externalised rather than internalised values making satire difficult. Wells sees other factors - including censorship, and a cultural lack of familiarity with reading and appreciating satire - as contributing to, though not completely explaining, this phenomenon (Wells 2006: 206-207). Nonetheless, she acknowledges this culture is subject to historical change, and suggests that in the future if people's personal and 
social aspirations are not met, satire could potentially increase (Wells 2006: 212-213). Corporate culture also restricts aggression. These newspapers are large commercial companies, and as such tend to be conservative, not wanting to upset or offend readers or advertisers. The Asahi Shinbun cartoonist Yamanoi No-rio (2007) has suggested one reason for newspapers' reluctance to allow their cartoonists to be critical of businesses in particular is that newspaper income streams rely on advertising rather than subscription money. Furthermore, he sees the structure of Japanese newspaper companies as encouraging self-censorship. According to Yamanoi (2007), there are no career journalists or career editors in Japanese newspaper companies. Rather than working in areas of specialisation, most employees instead tend to follow a company career path based on climbing the company ladder. Employees start out as journalists, and work for promotion through a series of editorial posts of increasing responsibility and, if all goes well, eventually move into a high ranking management position. Because of this, Yamanoi says that many employees during their three or so year tenure in an specific editorial position do not want to jeopardise their promotion chances by causing problems or controversy, so they are overly cautious with the cartoons they allow (Yamanoi 2007).

Another area where Japanese political cartoons are restricted is in cartoonists' habit of peopling almost every cartoon with non-offensive and rather cute caricatures of politicians. For the political cartoonist Yokota Shigi, caricature is absolutely central to his art, and is the aspect he puts the most effort into, and is dismissive of cartoonists who cannot caricature (Yokota 2014). The caricatures in Japanese political cartoons tend to be clean-lined figures and short in stature, similar to simple stylised comic-striplike characters. There is little or no attempt to represent Japanese politicians as ugly, sinister or immoral in appearance or in action, as is common in cartoons in other countries, for example politicians in the works of Steven Bell in Britain, or David Rowe in Australia. It is also rare for Japanese cartoonists to make any attempt to dehumanise their subjects, at least in a negative or frightening manner, the way British cartoonist Gerald Scarfe does at times - for example his depictions of Margaret Thatcher variously as a shark, a vampire-like creature, a "Torydactyl", and a fearsome battleship. This limits the amount of satirical aggression expressed in Japanese cartoons. Moreover, while these caricatures of politicians and historical drama metaphors are commonplace, the excessive use of caricature seems to impede Japanese mainstream cartoonists' from imagining more abstract metaphors convey their cartoon message (Asahi's Yamada Shin is the only exception, occasionally drawing on a broader variety of metaphors).

After 3.11, with the national sense of crisis and urgency, along with the above mentioned anger and dissatisfaction with the government and TEPCO, and intense public debates over energy and the country's future, that unfolded in the months that followed, how did these mainstream newspaper cartoonists react?

At first, it appeared that cartoonists and/or their newspapers did not know how to respond to the enormity of the situation. Was the humour of a cartoon comment appropriate at a time like this? The Yomiuri Shinbun printed its first cartoon four days after the disaster. Asahi Shinbun printed its first cartoon five days after the disaster, but uncertainty led them to stop and start, with no cartoons the following week and none again in the first week of April. Mainichi Shinbun stopped cartoons altogether for over six weeks. Its first related cartoon on 3 May was a bland call for unity and support for the government, echoing the first reactions of the other newspapers and Kyodo News. 
As time progressed, it became apparent that nothing much had changed with political cartooning. Of the 175 political cartoons from the big three dailies and Kyodo News surveyed for this paper from the first four months after 3.11, almost all, over 95\%, featured caricatures of politicians, the Prime Minister appeared in 77\%. Anti-nuclear campaigner and former Asahi Shinbun social cartoon contributor Hashimoto Masaru writing on the now defunct online news website The News about five months after 3.11, criticised the cartoons in the major newspapers asserting that

the reason why they are no good is that they are just caricatures (nigaoe) of politicians about the world of politics (seikyoku), and for this reason they never pursue substantial political or social problems. They just end up being cartoons making fun of superficial aspects of politics. One cannot but think that ideas (shisō) and opinions (iken) are not expected from cartoonists. For example, when it comes to the problem of nuclear power generation, before or after the Fukushima nuclear power plant accident, they have drawn nothing about it in the newspapers.

(Hashimoto 2011)

So, 3.11 brought about negligible change in the cartoons of the major dailies, or of Kyodo News. However, it did give birth to a regional newspaper cartoonist who has broken significantly from this form of cartooning. And whose anger at the treatment of disaster victims has led him to produce some aggressive satire that could be classified in Manning \& Phiddian's (2004b) savagely indignant cartoon category. Let us now turn our attention to this cartoonist and his work.

\section{Asakura Yūzō's Disaster Picture-Diary}

On 1 May 2011, the newspaper Fukushima Minpō began a weekly cartoon spot called Disaster Picture-Diary by local artist Asakura Yūzō on the Everybody's Plaza (Minna no hiroba) readers' page of their Sunday edition. The newspaper has a circulation of over 250,000 and is headquartered in Fukushima City, the second largest city in Fukushima Prefecture. Asakura is a retired high school art teacher who was seventy-one years old when he began his cartoon for the newspaper. $\mathrm{He}$ is a resident of Minamisōma, a town that had a population at the time of the disaster of just over 7,000. Located on the coast of Fukushima Prefecture, its southern border is only about 10 kilometres north of TEPCO's Fukushima Daiichi Nuclear Power Plant where the multiple reactor meltdowns occurred. Asakura's hometown was badly affected by the 3.11 disasters. The tsunami reached over two kilometres inland flattening much of the town adjacent to the seashore, and many remaining buildings suffered earthquake damage. The southern one third of the town lies within the 20 kilometre evacuation zone, or "Restricted Zone," and a further one third of the town lies within an "Evacuation-Prepared Area in Case of an Emergency" zone (Samuels 2007: 18). The town mayor became famous, even making Time magazines list of the world's 100 most influential people, after posting on YouTube an English captioned video appeal for help for his town. In it he "lashed out at Japan's political and economic establishment" for ignoring his calls after the central government with their arbitrary zoning left thousands of his citizens stranded and his municipality almost impossible to administer (Kyodo 2011). Asakura too had been evacuated at the time he began serialising the Disaster 
Picture-Diary. However, he was later able to return to his home and studio. The view from his home now overlooks rows of cramped units of one of the temporary housing areas built by the central government where evacuees still reside more than three years after the disaster.

Fukushima Minpō announced the start of serialisation of Asakura's Disaster Picture-Diary cartoon in an accompanying article roughly seven weeks after the disaster. In it the artist's intentions were quoted, "I want to express the situation in the disaster affected area, and the existence and thoughts of evacuees through their daily lives" (Fukushima 2011). The article hints that initially there was no planned schedule for serialising the cartoon, saying it would be printed as occasion demanded. However, it soon settled into a regular Sunday spot, and has now continued for over three and a half years. The article also notes that the title of the cartoon Disaster Picture-Diary is written in Asakura's calligraphy, and that apart from being a former art teacher, he is a member of the Prefectural Art Association and the National Ink Brush Picture (suibokuga) Association, as well as being a horse painting competition judge (horses are an important part of traditional culture in the region). Indeed his traditional style ink paintings and images of horses have adorned local calendars, illustrated a local folk tale publication and been exhibited in regional as well as national exhibitions. On occasion he has won prizes for his artwork, as he did again in 2014 at the National Ink Brush Picture Exhibition in Tokyo (Fukushima 2014). This experience in traditional ink painting is visible in his cartoons and marks them as different from mainstream political cartoons in Japan. However, he is not limited to just one style of drawing and his cartoons range from traditional brush line (at times allowing controlled bleeding of ink into the paper) images to more realistic depictions, and right through to the more cartoonish images and caricature one usually expects in political cartoons.

With much more emotional investment in the disaster-struck area and speaking primarily to a sympathetic audience in the region, Asakura addresses a much greater variety of meaningful themes and problems for the region than the narrow world of national politics. Of the 129 Asakura cartoons surveyed (May 2011 to December 2014) for this study politicians appear in less than $15 \%$. Only $9 \%$ of his cartoons feature the Prime Minister, a vast difference from the $77 \%$ in major newspaper cartoons surveyed. Asakura is capable of elevating his subjects in depicting tragedy, celebrating life, and in deploying humour to highlight ironies of life in the disaster affected area. He is also capable of angrily cutting down subjects through satirising those who are insensitive, incompetent or immoral. Below I will give examples of his range and attempt to highlight how these cartoons differ from the mainstream of newspaper cartoons in Japan.

\subsection{Recording devastation, elevating subjects and celebrating life.}

The first of Asakura's Disaster Picture-Diary images (Figure 1) was a realistic sketch of a large fishing boat, damaged and strewn with debris, sitting across National Highway no.6 in the Kashima District of Minamisoma City. It expresses the enormity of the disaster, but the cars in the foreground passing by the boat hint at a willingness to get back to life. The image is no doubt more powerful for locals who would be aware 
that this highway, National Highway No.6, which runs more or less parallel to the coast, is about two and a half kilometres from the sea at the point depicted.

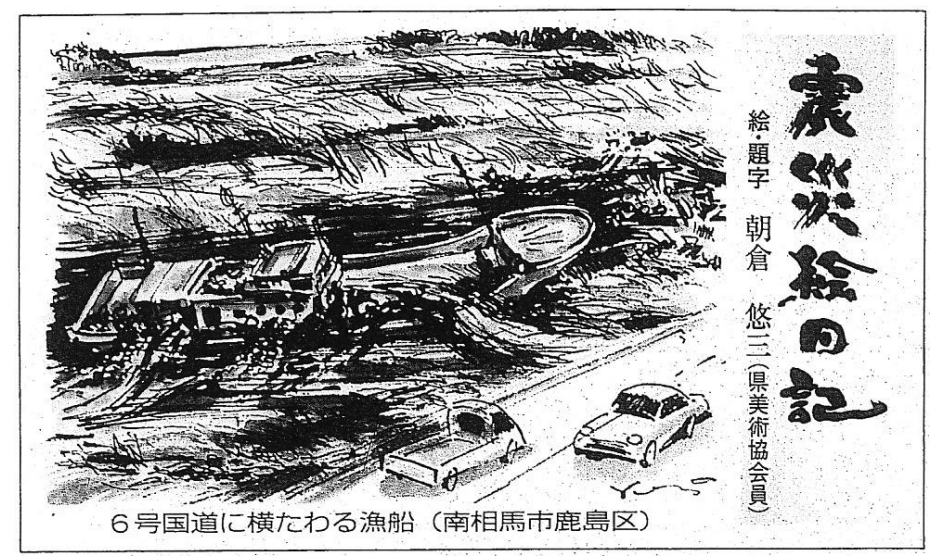

Figure 1. Asakura Yūzō's Disaster Picture-Diary, "Fishing boat lying across National Highway no.6 (Kashima District, Minamisōma City.)”. Fukushima Minpō, 1 May 2014, p. 12.

Quite a number of his cartoons celebrate life and events both in the region (local traditions and festivals), and nationally (national sporting and other achievements) that lend some normalcy to life, that make welcome distractions, and/or which convey messages of hope. Examples are his cartoons of: a "brief moment of peace of mind" showing evacuees enjoying the annual hanami (cherry blossoms viewing) in nearby Aizuwakamatsu City (8 May 2011: 12); an image of a warrior on horseback, a symbol of local "samurai spirit" and horse culture, to celebrate the restart of the area's traditional horse festival, Sōmanomaoi (17 July 2011: 15; 29 July 2012: 23); an injured boy watching television leaping out of his wheelchair as the Japanese National Women's Football Team win at the FIFA Women's World Cup (31 July 2011: 19); and of flag waving celebrations over a partial restart of the local train line (25 December 2011: 21). Among other cartoons were more restrained celebrations of the strength and perseverance of evacuees living in temporary housing. One example is a cartoon of people picking up and pouring affection on stray cats and dogs that wonder into the temporary housing areas (30 September 2012: 15). Another, perhaps a view over the nearby temporary housing area visible from the artist's own home, is the cartoon (Figure 2) captioned, "Every morning, my heart is warmed by the sight of an elderly couple walking arm in arm." It depicts an elderly couple arms linked walking through the temporary housing area. The cartoon elevates them, by giving them dignity in a difficult situation, and sending a message of hope. Cartoonists from major Japanese dailies also on rare occasions seek to elevate, but usually on the occasion of the death of a statesman or other famous person, such as on the death of Nelson Mandela, rather than the struggles of everyday people. 


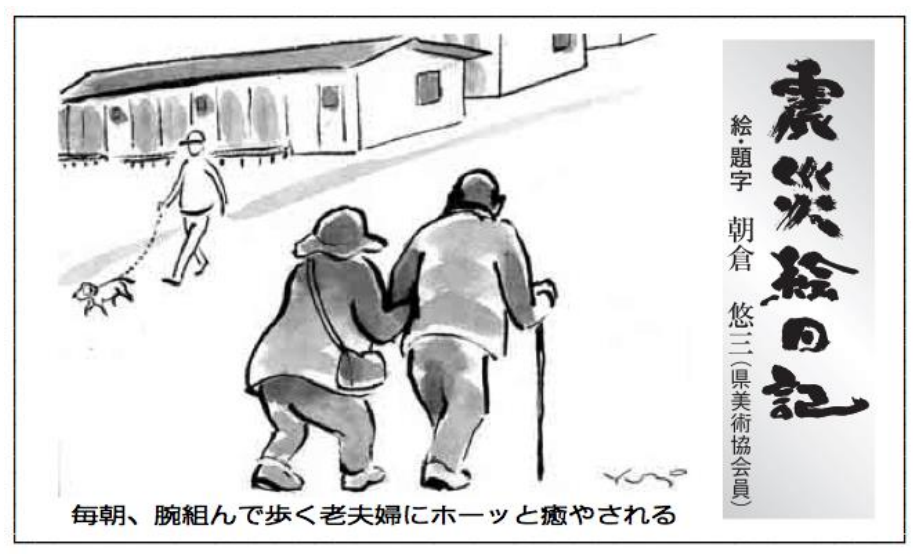

Figure 2. Asakura Yūzō's Disaster Picture-Diary, "Every morning, my heart is warmed by the sight of an elderly couple walking arm in arm". Fukushima Minpō, 28 October 2012.

\subsection{Bitter ironies of life in the disaster area}

Agriculture and fishing both play a large role in the economy of Fukushima Prefecture. Its rice production was the fourth largest in of 47 prefectures in Japan in 2010, but this dropped to seventh after 3.11. Farmers from the 20 kilometre no-go zone could no longer attend their farms, nor could those outside the zone whose farms registered caesium levels above the allowable limit, a situation which devastated many farmers (Aoki 2011). Also despite extensive decontamination efforts, concerns over food safety, real or imagined, remain affecting sales and making a return to farming difficult. The fishing industry was also hit badly by 3.11. Apart from the loss of fishing fleets and harbours, destroyed by the tsunami, continued dumping and runoff of contaminated water used to cool the TEPCO's damaged nuclear reactors plagues the reduced-size fishing industry's attempts to rebuild as restrictions are lifted. At times, Asakura in his cartoons picks up on the sad irony of having one's identity and way of life revolve completely around farming and fishing, yet not be able to engage in these activities. In one example, his cartoon shows a farmer and fisherman in a supermarket. The sad faced farmer pushes a shopping trolley containing vegetables and a sack of rice, while the fisherman browses the filleted fish packed in Styrofoam trays in the fish section. It is captioned, "the bitter feeling of disappointment of a farmer buying rice and vegetables and fisherman buying fish" (4 November 2012: 21). In another example (Figure 3), an elderly woman looks on as a famer (possibly her husband or son for whom she has brought lunch) tills land he knows he cannot farm because he cannot relax unless he is working his land. Even though evacuees faced difficult social, economic and mental health problems as a result of the changes in their lives brought about by 3.11, mainstream cartooning did not attempt to highlight or comment on these problems. 


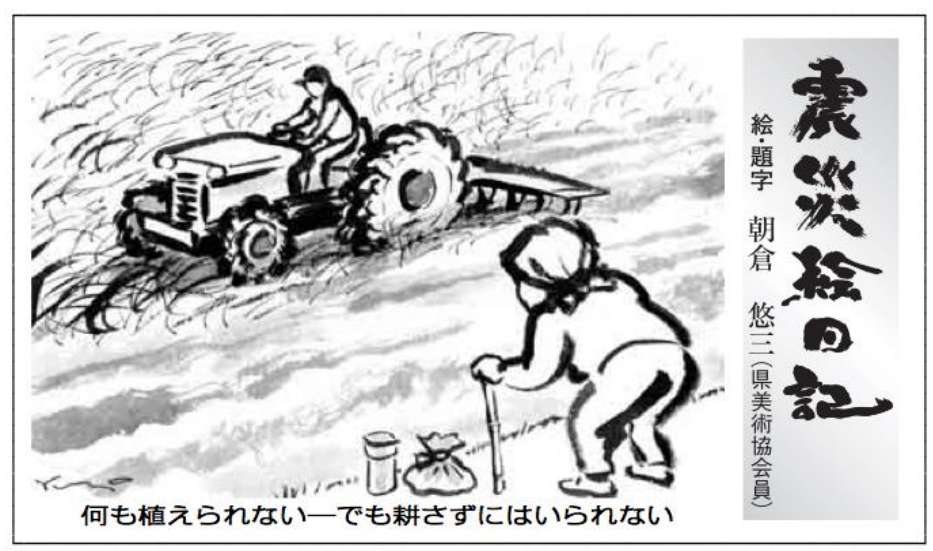

Figure 3. Asakura Yūzō's Disaster Picture-Diary, "He can't plant anything... but he can't relax unless plows his field". Fukushima Minpō, 29 April 2012, p. 19.

Asakura also points out the ironies of national and local support for victims of the disaster not bringing about the expected results. One cartoon drawn a year and a half after the 3.11 depicts a forlorn faced elderly woman crouching beside a broken gravestone in a cemetery flattened by the disaster and now overgrown. She wonders what has happened to the huge recovery budget, as it looks like only a pittance has been spent here (16 September 2012: 25). In another, an elderly man pushes his wife's wheel chair away from an evacuation area, possibly to return to their home (16 October 2011: 18). The wife holds a parting present of flowers, and supporters and other evacuees cheer and call out wishing them luck. The words they use are all variants of the term ganbaru. This is often equated to the English term "good luck," but literally means to "keep trying", "give it your best shot", "keep it up", "don't give up". It became somewhat a hollow mantra through overuse in the wake of 3.11. According to scholar Richard Samuels, the expression Ganbaro Nippon! (Let's hang in there together, Japan!) became ubiquitous, appearing on posters, in bookstore promotions, and even in lights on Tokyo Tower. He notes also that a Google search for the expression six months after the disaster produced 23 million hits (2013: x, xiii, 40). In this cartoon the elderly couple respond to these words of encouragement, "Sigh. How are we supposed to "hang in there'?" One 60 year old reader in a letter to the newspaper responding to the cartoon expressed feeling the same sentiment. Having been forced to leave her home due to radiation, then evacuate temporary housing due to flooding, she has received lots of support and tried to her best to hang in there. But with failing health and nothing but bad news on television, she wanted some relief from 'hanging in there.' When she read the caption of this cartoon, her "thoughts went running and tears welled in her eyes" (22 October 2011: 17).

\subsection{Satire aimed at bureaucrats and agencies}

Unlike the major newspaper cartoonists who never take bureaucrats to task for their words and actions, Asakura has at times not been shy about pointing out their incompetency, insensitivity and overly close relationship with business and elected government. In one example (Figure 4) he takes aim at the Ministry of Environment. 
The ministry issued guidelines on how people in the affected areas should decontaminate their own properties to reduce caesium levels: people were advised to wear protective clothing and masks, remove leaves from rooftops, hose down homes and remove the top layer of soil from around their homes (Aoki 2012). However, the ministry gave little indication about what to do with the bags of contaminated refuse resulting from this. Much was left to individuals and regional governments to deal with. Asakura satirises this half-measure by central bureaucrats. He depicts a glum faced man leaning out of his sparklingly clean decontaminated home, his decontamination tools in front of him, but his home is surrounded by mountains of bagged contaminated soil and leaves resulting from the cleanup. The caption reads, "I've decontaminated my home, but...".

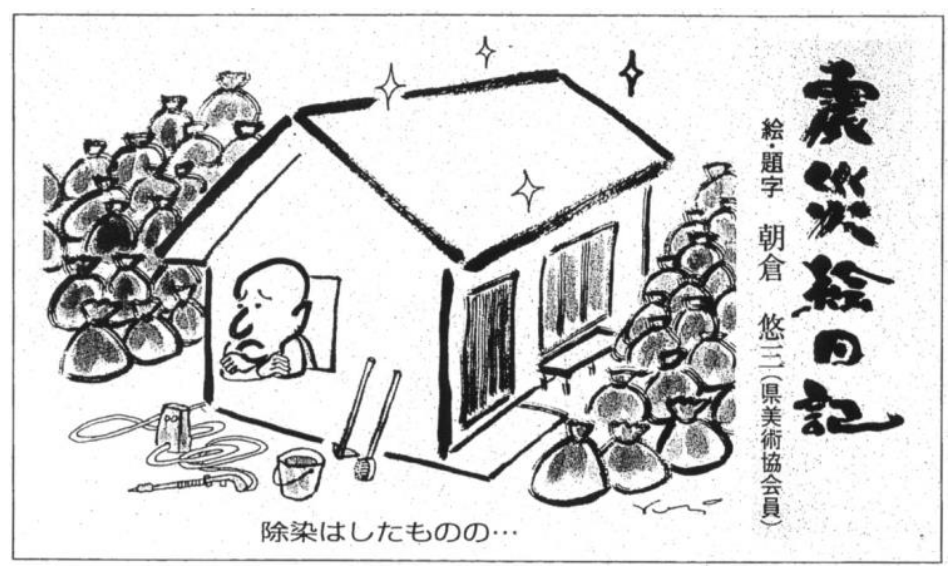

Figure 4. Asakura Yūzō's Disaster Picture-Diary, "I've decontaminated my home, but...". Fukushima Minpō, 3 September 2014, p. 10.

In another cartoon (26 August 2012: 21), Asakura is critical of the unhealthily intimate relationship between supposedly independent agencies, part of the so called 'nuclear village', the name given in Japan by critics to the overly cosy ties between pro-nuclear policy makers, bureaucratic agencies, manufactures, sections of the media and academia, and, of course, the power companies (see Kingston 2012b; Samuels 2013: 118-123). In the cartoon two drunken middle-aged men stagger home with arms around each other's shoulders in a friendly embrace after a night on the town celebrating their long friendship. One of them represents the Nuclear and Industrial Safety Agency, a branch of two central government ministries charged with responsibility for nuclear industry regulation and oversight. The other represents the Nuclear Safety Commission, a nominally independent agency that administered nuclear safety, its members appointed directly by the Prime Minister. The cartoon was drawn after the decision to dissolve both of these agencies in order to create greater separation. The caption bluntly lays blame for the scale of the nuclear disaster on their lack of independence, "A long 'intimate friendship' (nareai) that made worse the nuclear accident."

Asakura's anger at bureaucratic insensitivity to the feelings and fears of disaster victims was also vented in his cartoons. In a cartoon (Figure 5) titled, "Stupefied by the invective tweet that stepped on the feelings of disaster victims", the giant foot of a senior official of the government's post 3.11 Reconstruction Agency steps and crushes people of the disaster affected area. As councillor in charge of implementing the law to 
support children and adults affected by the radiation from the Fukushima Daiichi Nuclear Plant accident, he attended a community gathering about health concerns in the area. While returning to Tokyo he wrote on his Twitter account that they were a bunch of "shit head lefties" and that he feels "pity for their lack of intelligence" (Asahi 2013; Japan Today 2013). Here in this cartoon is also an implied critique of the government's complicity in the 'nuclear village' with its seeming prioritisation of business over concerns for people's health and safety. The cartoon would fit into Manning \& Phiddian's (2004b) savagely indignant cartoon category. Unlike Asakura, the cartoonists in the major dailies, who almost never make members of the bureaucracy subjects of their work, did not offer any cartoon commentary, much less criticism, on this piece of news.

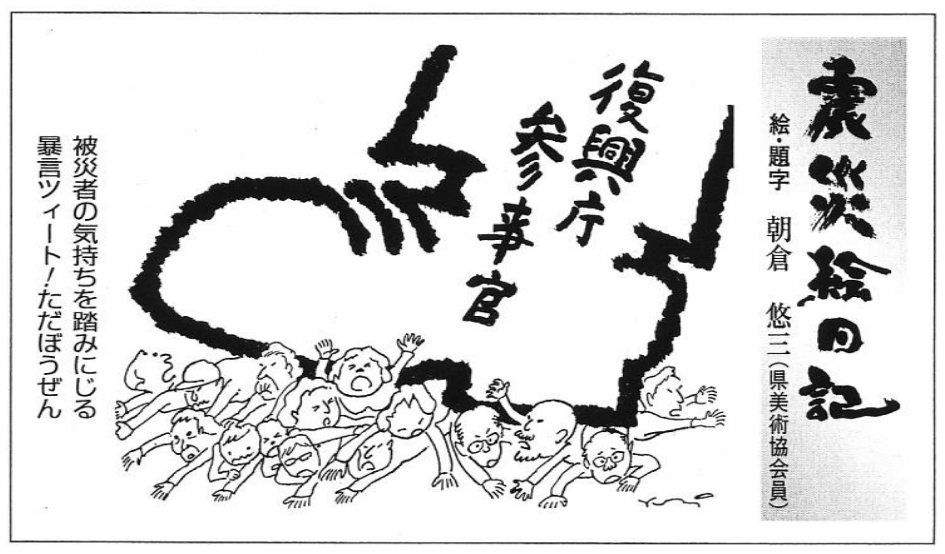

Figure 5. Asakura Yūzō's Disaster Picture-Diary, "Stupefied by the invective tweet that stepped on the feelings of disaster victims" (giant foot = "Senior Official, Reconstruction Agency'). Fukushima Minpō, 23 June 2013. p. 22.

\subsection{Satire aimed at corporations}

Another section of society that mainstream newspaper cartoonists almost never comment on is the corporate world. Apart from the large business concerns like Japan's various power companies being an important source of revenue for newspapers, in the case of TEPCO, the big three newspapers and their journalists are intertwined with the company in complex ways (Birmingham 2012: 95). In particular the Yomiuri Shinbun - an unabashed supporter of the nuclear industry whose former owner, Shoriki Matsutarō, was considered the "father of nuclear power" in Japan - is rarely critical of the nuclear industry in any way. Its cartoonists did not comment on TEPCO or its actions at all in the wake of 3.11. While the Asahi Shinbun is the most vocal critic of TEPCO in print among the major news organisations, its cartoonists too did not turn their pens to the company in the cartoons surveyed for this study. Only two cartoons addressing TEPCO were found, one Kyodo News cartoon and a Mainichi Shinbun cartoon. Kyodo's Arai Tarō questioned concreteness of TEPCO's stated plans to control the situation a month after the disaster. In his cartoon a hand holds a "concreteness" metre, in the shape of a radiation (or lie) detector, in front of TEPCO president Shimizu's mouth as he speaks (15 April 2011). Mainichi's Yokota Shigi drew a cartoon 
of Prime Minister Kan Naoto, along with members of the nuclear regulation agencies and TEPCO's Chairman all repeating the expression "beyond imagining" (sōteigai), a term they oft repeated to describe the scale of the disaster and inability to foresee and plan for it, but the term was seen by a large portion of the public as an attempt to escape responsibility for a lack of planning and incompetence. This is reflected in the calls from a crowd of people in the foreground of the cartoon, "your irresponsibility is beyond imagining" and "incompetence beyond imagining" (21 May 2011).

In contrast to the national newspaper cartoonists, Asakura has been frequently and consistently critical of TEPCO. One angry cartoon he drew was of the company president's attempt to escape responsibility for the nuclear accident or for dealing with the aftermath by giving up his job. In Japan it is common for company presidents and public officials publicly to apologise and resign their position to "take responsibility" for problems caused under their leadership. In Asakura's cartoon TEPCO president Shimizu bows deeply in apology before an angry crowd of victims while he gleefully glances behind to a large moneybag labelled "retirement payout" which he clutches behind his back. The caption reads, "A Japanese-style apology - 'I take responsibility... and quit!"' (14 August 2011: 18). At the time rumours had spread over the internet that he received approximately five million U.S. dollars as a golden handshake. Asakura was also critical of TEPCO's obfuscation and covering of information. One of his cartoons depicted a businessman submitting a report done "TEPCO-style" with most of the information blacked out to an angry superior (9 October 2011: 23). On a number of occasions Asakura also expressed his frustration with TEPCO's inability to control the leaking of contaminated water into the sea, for example his cartoon showing King Neptune rising from the sea, threatening the nuclear plant with his trident and telling them to stop (25 August 2013: 21). Asakura also satirised TEPCO's insensitivity and incompetence in regards to their compensation payment procedures for victims. The first compensation claim forms distributed by the company in September 2011 were extremely long and complicated. The application form was fifty-six pages in length with over 2000 questions, and was accompanied by a 156-page instruction manual. Moreover, despite many people having lost their possessions, the application required actual documentation (not copies) of expenses and pre-3.11 income. If approved, payments would last for a mere three months, after which reapplication would be necessary (Inajima 2011). Asakura's cartoon reaction to this (Figure 6) was an image of a man reeling over in a state of shock, his eyes spinning after seeing the compensation procedures. His wife calls out to the ambulance stretcherbearers running to the scene, "As soon as he opened the pages he came over all woozy." 


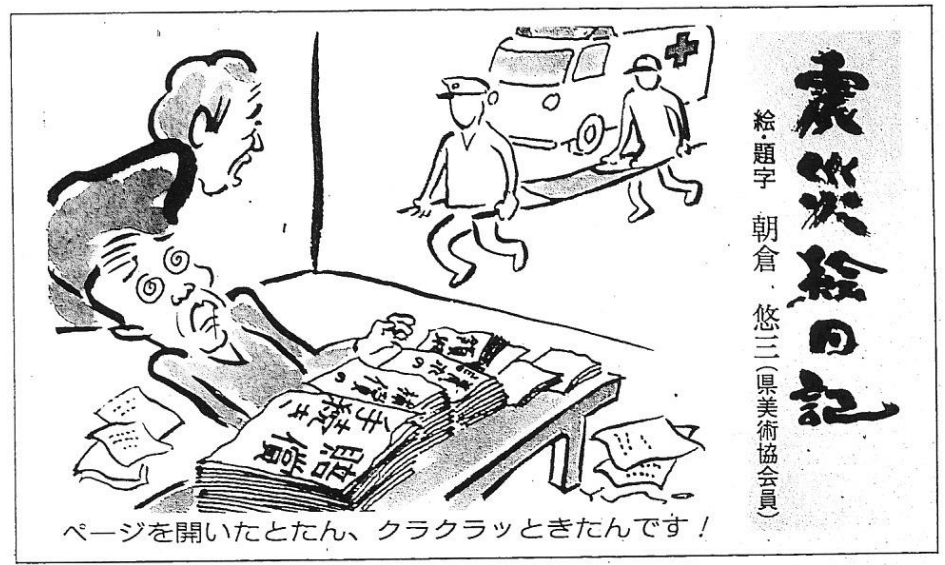

Figure 6. Asakura Yūzō's Disaster Picture-Diary, "As soon as he opened the pages he came over all woozy" (Paper pile = 'compensation application procedures'). Fukushima Minpō, 2 October 2011, p. 19.

\subsection{Satire aimed at politicians}

Asakura, just as the cartoonists of the big three dailies and Kyodo, took to task politicians over their statements, their politicking and inaction in implementing needed reconstruction policies. However, while not doing this as often as these national paper and nationally syndicated mainstream cartoonists, his cartoons were done from a local perspective and carried more urgency. Two ways in which he achieved this was with his inclusion of, as in some of his work described above, victims of the disaster in his cartoons, and through his use of caricatures that are a little less stylised and cute than the mainstream cartoonists. An example of this is his cartoon from 12 May 2012 (Figure 7) of the then Prime Minister, Noda Yoshihiko, fighting with the leader of the parliamentary opposition Tanigaki. In it he caricatures these two politicians in front of the Japan's distinctive parliament building, Diet, fighting in shorts and carrying bamboo swords to suggest they are squabbling like children in a playground. This is close to the way mainstream cartoonists approach the world of politics in their cartoons. However, what sets his cartoon apart are his use of a brush rather than a pen, making the lines inconsistent and giving the characters a rougher edge, and importantly, his inclusion of disaster victims. The caption reprimands the two political leaders in the manner an adult would with mischievous children, "Enough of this sort of thing. Talk about something more important!". The cartoon makes clear what is more important by showing the dark, tired and sad figures of victims in the foreground. The only comparable cartoon depicting victims amongst the major newspaper cartoons surveyed, is a powerful image by Asahi Shinbun cartoonist Yaku Mitsuru depicting the Prime Minister at the time of the disaster, Kan Naoto, and the opposition leader endlessly debating leadership while surrounded by disaster evacuees in the terrible conditions of the earliest evacuation areas, sad faced and cramped together in makeshift cardboard partitioned spaces on the floors of school and public halls (18 June 2011). 


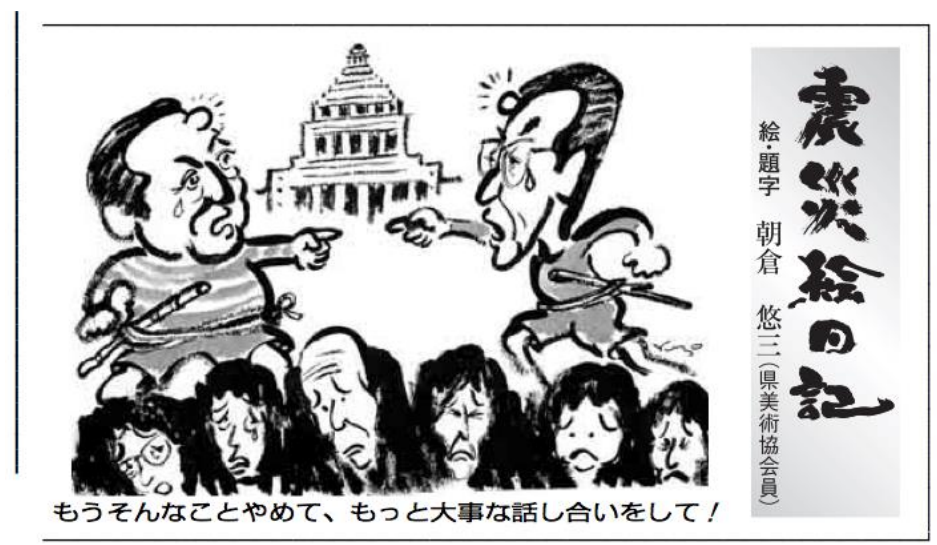

Figure 7. Asakura Yūzō's Disaster Picture-Diary, "Enough of this sort of thing. Talk about something more important". Fukushima Minpō, 20 May 2012, p. 19.

Asakura also offered strong cartoon criticism of the Prime Minister. He reflects the fears of his region concerning their plight may be forgotten by the government with its own new separate set of agendas, and forgotten by a Tokyo-centric national media excited by news of the Tokyo Olympics, but progressively growing numb to news post-disaster reconstruction and nuclear reactor cleanup. One cartoon depicts Japan's new nationalist Prime Minister Abe Shinzō in a military helmet stumbling forward past disaster victims and towards a rifle on the ground, arms outstretched in front of him as he reaches ahead to pick the weapon up (12 May 2013: 23). The hawkish Abe after gaining office with his Liberal Democratic Party in September 2012 was soon openly pushing to revise the country's peace constitution, to allow the self-defence forces to be rearmed and deployed overseas, and eager to restart the nuclear power industry and sell its technology overseas, throwing out the previous ruling party's decision after 3.11 to phase out nuclear power. This cartoon criticises Abe only looking towards his military ambitions while disaster victims fall out of his field of vision. Its caption carries the voice of the victims, "Have you forgotten about the disaster area? Isn't he pitching forward (past us) more and more...". In September 2013, while the mainstream newspaper cartoonists were drawing cartoons to celebrate Tokyo being awarded the 2020 Olympic Games, Asakusa in a mock celebratory cartoon filled with cheers, rockets and fireworks, but no caricature, throws Prime Minister Abe's own words back at him (15 September 2013: 16). The words are paraphrased from Abe's speech before the International Olympic Committee playing down concerns about radiation and assuring them of the safety of Tokyo as an Olympic venue. After Abe's claim that, "the leaking contaminated water is not a problem at all!" Asakura adds a question mark. He also repeats Abe's assertion that, "Tokyo is safe (Tōkyo wa anzen desu)," but emphasises Tokyo and makes use of a contrastive Japanese subject marker " $w a$ " to imply that Tokyo is safe, but other places, namely the affected area in Fukushima, may not be. The caption is again a clear reminder, "Don't forget Fukushima!!" There were no cartoons critical of the Olympics bid in the major dailies.

Another cartoon depicts Abe as two faced on nuclear power (19 May 2013: 17). Abe is drawn with two faces pointing in opposite directions. One looks to the Japanese public admitting to them that, "When it comes to nuclear power, nothing is absolutely safe," and his other face turned towards the Prime Minister of Turkey with whom he 
shakes hands, completes his sentence, "but... we'll export it." On 3 May, Abe had concluded a deal for Japanese companies to build Turkey's second nuclear power plant. The caption for the cartoon suggests Abe's lack of concern over what happened at Fukushima and its continuing problems, "As if nothing happened... a look of indifference."

Asakura's cartoon commentary on politicians, while not as frequent as in national paper cartoons, is in general more biting and regularly questions aspects of political agendas the mainstream cartoonists rarely touch directly upon, in particular politicians' apparent lack of consideration for victims and the disaster hit regions.

\subsection{Questioning nuclear power}

A final area where Asakura differs from the cartoonists in the major dailies is his questioning of the use of nuclear power. This is an issue Asahi, Mainichi and Kyodo cartoonists rarely visit and which Yomiuri cartoonists never touch. His cartoons on the subject show his ability to use metaphors, showing that it is possible for Japanese cartoonists to make political cartoon comment without reliance on caricature. One of his cartoons shows a sports car with a large engine (a metaphor for a high tech nuclear reactor) accelerating uncontrollably forward while leaving behind its driver still holding the steering wheel that has broken away in his hands (3 July 2012: 15). It is captioned, "Now we know that mankind can't control nuclear power." In one of his most striking images (Figure 8) he drew four cages, echoing the shapes of reactors one to four at the Fukushima Daiichi Nuclear Power Plant, with a fearsome looking dragon in each representing the radiation inside the reactors, potentially dangerous if they escape. In front of the cages, a top hat wearing sideshow barker, or circus ringmaster, no doubt representing the promoters of nuclear energy from Japan's "nuclear village," assures the gathered crowd that the danger is completely under control by saying, "It will never get out and cause havoc". Asakura followed this cartoon the following week with a frightening image of the dragons bursting out of their broken cages and the people who had been gathered around fleeing for their lives (5 June 2011: 19). It is captioned, "the safety myth destroyed!"’.

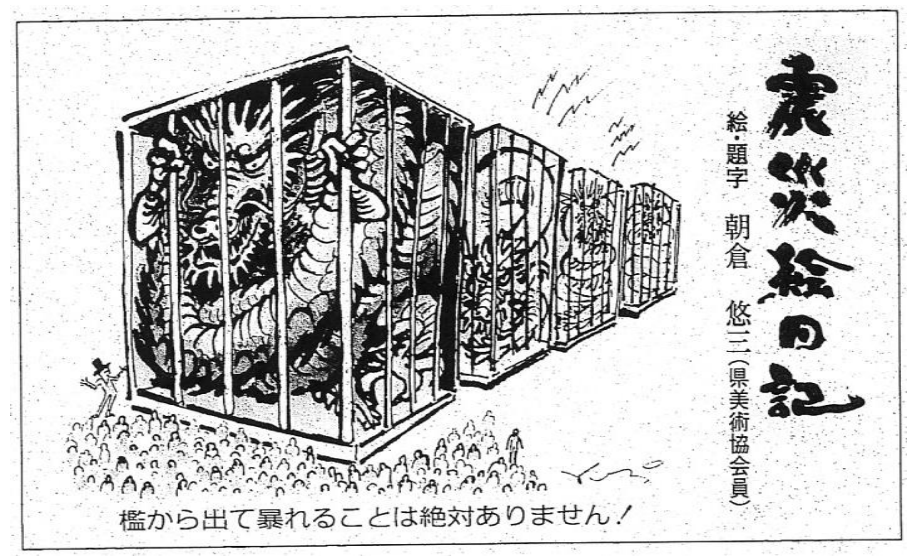

Figure 8. Asakura Yūzō's Disaster Picture-Diary, "It will never get out and cause havoc". Fukushima Minpō, 29 May 2011, p. 14. 


\section{Conclusion}

The immensity of Japan's 3.11 disaster did not wake mainstream Japanese political cartooning from its long state of torpidity. However, it did give birth to a new, though elderly, regional political cartoonist, Asakura Yūzō, who did break with their narrow form of cartooning. As can be seen from the above examples and comparison, Asakura's Disaster Picture-Diary cartoons differ from the "big three" national daily newspapers and Kyodo News' political cartoons in the variety of styles he employs, his ability to escape their reliance on 'cute' caricatures and to use abstract metaphors, and his willingness to address a broader range of issues and subjects. In the wake of 3.11, while the mainstream political cartoonists focused almost purely on poking light fun at national politicians, just as they have done for decades, Asakura drew attention to life and needs in the disaster affected areas, calling attention to reasons for needing help and reasons for having hope. He has aimed his satirical brush not only with more anger against national politicians, but also to question and criticise bureaucrats, agencies, corporations, and nuclear power. All of these are subjects rarely touched by the mainstream cartoonists. Asakura's work provides a model for other regional papers without cartoonists to engage in meaningful cartoon commentary for their regions, and a model for how the mainstream nationally based cartoonists could make their work more varied in style and subject, more engaged with broader issues, and more relevant. Following his model could give mainstream cartooning more vigour, more popularity, and a greater and more meaningful role in public discourse. One can only hope that they will take notice.

Why has Asakura been able to break with the mainstream mold like this? Here I will put forward four provisional reasons. One is no doubt his age. Asakura grew up in a period when post-war Japanese cartooning was at its best. A period when single panel cartooning was more popular with adults than comics, a situation that had reversed by the late 1960s. It is probably no coincidence that he is exactly the same age as the most aggressive and imaginative of the mainstream cartoonists, Asahi Shinbun's Yamada Shin, who also turned 74 years old in 2014.

A second reason for breaking the mainstream mold is that Asakura does not come from a cartooning background. So rather than being used to, and conforming to, the dominant cute drawing style of recent decades, he draws on his experience painting horses and doing traditional ink brush painting in creating his cartoons, giving them a different look to the mainstream cartoonists.

The third reason is limited circulation. Drawing primarily for Fukushima Minpō's quarter of a million readers, he is talking to a relatively small and mostly sympathetic audience. While some of his cartoons have made it onto the Internet, his limited exposure no doubt translates to less complaints or external pressure from corporations, politicians or their followers. National daily newspaper cartoonist Yokota Shigi of Mainichi says cartoons regularly draw complaints, but he tends to avoid satirising political subjects that draw difficult-to-deal-with (mendokusai) complaints. Yokota gave two examples, one a politician that makes aggressive direct legal threats if satirised, and a political leader whose supporters from extreme right-wing fringe groups overwhelm the paper with complaints via the internet when his is drawn negatively in a 
cartoon (Yokota 2007). With less external pressure or complaints, Asakura and his editor(s) are no doubt able to offer more aggressive satire without Yokota's professed self-restraint (self-censorship).

A fourth reason why Asakura's cartoons are different from mainstream cartoonists is his local perspective. This makes him more understanding of, and more emotionally engaged with, the problems of the disaster affected region. Consequently, his cartoons have a greater sense of urgency and force in addressing these problems, and he has become a most persistent champion of local issues. There is an interesting parallel here with an environmental disaster in the United States. In the wake of the months long BP Deepwater Horizon oil spill in the Gulf of Mexico of 2010, the most persistent political cartoon commentator, satirising the response and actions of corporations, politicians and agencies involved was political cartoonist J. D. Crowe. Crowe lives near the city of Mobile, Alabama, one of the areas most affected by this disaster, and works for the local Mobile Press-Register newspaper. The locally engaged work of cartoonists like Crowe and Asakura speaks to the value and importance of regional, not just national, political cartoon voices.

\section{Note}

All images above are used with the kind permission of the artist, Asakura Yūzō. Research for this paper was funded in part by the Japanese Government's Grants-in-Aid for Scientific Research (Project Number: 24520170). Japanese names when written in full in this paper are in the Japanese order of family name followed by given name.

\section{References}

Aoki, M. (2012). 'Fukushima farmers in two-front war', in Kitazume, T. (ed.), The Japan Times Special Report - 3.11, One Year On: A Chronicle of Japan's Road to Recovery, Tōkyō: The Japan Times, p.19.

Asahi Shinbun (2013). 'Reconstruction official insults citizens groups, Diet members on Twitter'. The Asahi Shinbun, 13 June. URL: http://ajw.asahi.com/article/behind_news/social_affairs/AJ201306130069 [Accessed 23 January 2014].

BBC News Asia (2012). 'Japan quake: Loss and recovery in numbers', BBC News Asia. URL: http://www.bbc.co.uk/news/world-asia-17219008 [Accessed 13 August 2014].

Birmingham, L \& McNeill, D. (2012). Strong in the Rain: Surviving Japan's Earthquake, Tsunami, and Fukushima Nuclear Disaster. New York: Palgrave Macmillan.

Broinowski, R. (2012). Fallout from Fukushima. Melbourne: Scribe.

Bushby, H. (2013). 'Gerald Scarfe on how he loved to loathe Thatcher', BBC News. URL: http://www.bbc.com/news/entertainment-arts-22076837 [Accessed 18 August 2014].

DeSousa, M. A. \& Medhurst, M. J. (1982). 'Political Cartoons and American Culture: Significant Symbols of Campaign 1980'. Studies in Visual Communication 8, pp. 84-97. 
Edwards, J. L. (1997). Political Cartoons in the 1988 Presidential Campaign: Image, Metaphor, and Narrative. New York: Garland Publishing.

Fukushima Minpō (2011). 'Hisai gaka ga egaku "shinsai" [Disaster affected artist draws the "Disaster"]', 1 May, p.12.

Fukushima Minpō (2011). 'Minamisōma no Asakura-san togi kaigichō-shō zennihonsuiboku-ten, hisaichi ga daizai [Minamisōma's Asakura wins Tokyo City Council Chairman's Prize at National Ink Brush Painting Exhibition, Disaster area theme.]', 18 June. URL: http://www.minpo.jp/news/detail/2014061816359 [Accessed 10 August 2014].

Hashimoto, M. (2011). 'Naze shinbun no seiji manga wa "genpatsu" wo toriagenai no ka [Why don't newspaper political cartoons take up the issue of "nuclear power"?]". The News, 18 August. URL: http://the-news.jp/archives/6413 [Accessed 19 August 2011].

Ibaragi, M. (2007). Media no naka no manga [Cartoons in the Media]. Kyōto: Rinsen Shoten.

Inajima, T. \& Watanabe, C. (2011). 'Japan Evacuees Angered by Tepco Red Tape'. Bloomberg, 16 September. URL: http://www.bloomberg.com/news/2011-0916/evacuees-angered-by-tepco-compensation-forms.html [Accessed 20 August 2014].

Japan Today/AFP (2013). 'Reconstruction agency official suspended over Twitter tirade about Fukushima'. Japan Today, 22 June. URL: http://www.japantoday.com/category/politics/view/reconstruction-agency-officialsuspended-over-twitter-tirade-about-fukushima/comments/popular/id/3377652 [Accessed 23 January 2014].

Kasai, T. (2013). 'About 60 percent of Fukushima evacuees cannot return home by 2017'. Asahi Shinbun, 11 March. URL: http://ajw.asahi.com/article/0311disaster/recovery/AJ201303110005 [Accessed 13 August 2014].

Kyodo. (2011). 'Minamisoma mayor makes Time's influential list'. Japan Times, 23 April. URL: http://www.japantimes.co.jp/news/2011/04/23/national/minamisomamayor-makes-times-influential-list/\#.U_Hr6kjDJFN [Accessed 18 August 2014].

Kyodo Staff Report (2014). '267,000 still evacuees three years on'. Japan Times, 10 March. URL: http://www.japantimes.co.jp/news/2014/03/10/national/267000-stillevacuees-three-years-on/ [Accessed 10 March 2014].

Kingston, J. (2012a). 'Mismanaging Risk and the Fukushima Nuclear Crisis'. The AsiaPacific Journal 10 (12/4). URL: www.japanfocus.org/-Jeff-Kingston/3724 [Accessed 5 April 2012].

Kingston, J. (2012b). 'Japan's Nuclear Village'. The Asia-Pacific Journal 10 (37/1). URL: http://www.japanfocus.org/-Jeff-Kingston/3822 [Accessed 3 August 2014].

Kingston, J. (2014). 'After 3.11: Imposing Nuclear Energy on a Skeptical Japanese Public'. The Asia-Pacific Journal 11 (23/4). URL: http://www.japanfocus.org/-JeffKingston/4129 [Accessed 12 June 2014].

Kitazume, T. ed. (2012). The Japan Times Special Report - 3.11, one year on: A chronicle of Japan's road to recovery. Tōkyō: The Japan Times.

Manning, H. \& Phiddian, R. (2004a). 'Censorship and the political cartoonist'. Refereed paper presented to the Australasian Political Studies Association Conference, 29 September - 1 October. 
Manning, H. \& Phiddian, R. (2004b). 'In defence of the political cartoonists' license to mock'. Australian Review of Public Affairs 5 (1), pp. 26-42.

McQuail, D. (2010). McQuail's Mass Communication Theory (6 ${ }^{\text {th }}$ edition). London: Sage.

McNicol, T. (2005). 'Representing Hirohito in Wartime: the art of Arthur Szyk' (Interview with Sodei Rinjiro). Japan Focus, 3 November. URL: http://www.japanfocus.org/-Tony-McNicol/1608 [Accessed 7 July 2009].

Press, C. (1981). The Political Cartoon. Rutherford: Fairleigh Dickinson.

Samuels, R. J. (2013). 3.11: Disaster and Change in Japan. Ithaca: Cornell University Press.

Stewart, R. (2013). 'Hisai no tēma wo tōshite saguru nichibei seiji manga no hikaku (A Comparative study of Japanese and US political cartoons through the theme of disaster)'. Unpublished presentation at 'Kaigai no shinbun manga no sekai (The world of overseas newspaper cartoons and comic-strips)' Symposium (Japan Society for Studies in Cartoons and Comics, Kyoto International Manga Museum), 23 June.

Wells, M (2006). 'Satire in constraint in Japanese culture', in Milner Davis, J. (ed.), Understanding Humour in Japan, Detroit: Wayne State University Press, pp.193212.

Yamanoi, N. (2007). 'Manga and Japanese cartooning.' Presentation at Cartooning for Peace, Emory University, 15 November.

Yokota, S. (2014). Untitled presentation on his work as a cartoonist and illustrator given at the Japan Society for Studies in Cartoons and Comics. Cartoon Studies Group's $3^{\text {rd }}$ Study Meeting for the 2013 academic year. Common+ Ringokan, Kyōto, 8 February. 